\title{
Začíná nová éra sociologie volného času a životního stylu?
}

\author{
Ivan Chorvát, Jiř́ Šafr (eds.): Volný čas, společnost, kultura. \\ Česko - Slovensko \\ Praha, Sociologické nakladatelství (SLON) 2019, 248 s.
}

Kniha Volný čas, společnost, kultura. Česko - Slovensko je prvním ambicióznějším příspěvkem k sociologii volného času a životního stylu, jehož autory jsou sociologové dnešní střední a mladší generace. Tyto dva věcně spjaté obory patřily od šedesátých let minulého století $\mathrm{v}$ československé sociologii $\mathrm{k}$ těm nejsilnějším, ale po roce 1989 se dostaly do vleklého úpadku, jehož př́činy by stály za samostatnou studii. Nový zájem o klíčové téma životního stylu je pro českou sociologii dobrou zprávou. Specifickým př́nosem knihy je, jak už název napovídá, její česko-slovenský komparativní rozměr. Srovnání vývoje volnočasových aktivit a prvků životního stylu v České a Slovenské republice během posledních desetiletí je natolik důkladné a rozsáhlé, že kniha se nepochybně stane jednou z referenčních publikací pro sociologické studie o vývoji české a slovenské společnosti na mnoho dalších let, a možná desetiletí.

Krátce po vydání knihy propukla světová pandemie COVID-19, která vzorce trávení volného času a životních stylů bezprecedentním způsobem narušila. Pandemie může některé vývojové trendy urychlit, jiné dokonce trvale změnit, ale zatím je málo důvodů myslet si, že svět volného času po pandemii nebude vykazovat velmi výrazné kontinuity se světem, jak jsme jej znali dříve. V každém př́ipadě je cenné mít přehledně zpracovaný vývoj v některé oblasti společenského života až skoro do začátku pandemie, jako se to právě podařilo zde.

\section{Česko-slovenský rozměr}

Publikace, věnovaná stému výročí vzniku Československé republiky připomínanému v roce 2018, je dokladem toho, že česko-slovenská a slovensko-česká spolupráce v sociologii stále pokračuje a přináší důležité nové poznatky o obou společnostech. Text vznikl ze spolupráce pěti autorů a jedné autorky, z toho tří slovenských a tří českých. Každý text vyšel v jazyce svého autora, publikace je česko-slovensky bilingvní. Na tom není nic špatného, naopak, ale je třeba bohužel počítat s tím, že minimálně na české straně hranice tak knize ubudou čtenáři, zejména v nejmladších ročnících. Největší autorský podíl na knize má slovenský sociolog Ivan Chorvát, následovaný Jiřím Šafrem, oba jsou zároveň editory.

Česko-slovenské srovnání v oblasti volného času a životního stylu přirozeně nebylo možné provést dříve, než byla sesbírána vhodná srovnatelná data. $\mathrm{Na}$ české straně byl již v roce 2011 v rámci jiného projektu proveden výzkum kultur-

(C) Sociologický ústav AV ČR, v. v. i., 2021

(C) Autor, 2021 
ní participace české populace Kultura v regionech České republiky 2011 (ČR 2011). I. Chorvát připravil a vedl slovenský projekt, který umožnil provedení aspoň menšího omnibusového výzkumu Volnny čas na Slovensku (SR 2016) se stejnými nebo podobnými otázkami, jaké byly dříve položeny v českém výzkumu. Data z obou výzkumů, at' už samostatně, nebo harmonizovaná a spojená do jednoho souboru, tvoří hlavní podklad empirických analýz představených v této knize (viz př́loha zpracovaná J. Šafrem na s. 232 a násl.). Objektivním nedostatkem dat je fakt, že mezi českým a slovenským výzkumem uplynulo pět let, během kterých se svět výrazně proměňoval, ale stále jde o unikátní datový soubor, bez kterého by komparativního cíle knihy prakticky nebylo možné dosáhnout. Současně je třeba zdưraznit, že analytické kapitoly se opírají o celou řadu dalších výzkumů, zejména pravidelných mezinárodních šetření a také o jeden z velkých výzkumů československé sociální struktury provedených před rokem 1989.

\section{Teoretická východiska}

I když je zejména v kapitolách slovenského editora knihy I. Chorváta patrná snaha dodat knize jednotný obsahový a teoretický rámec, tento záměr se podobně jako u mnoha jiných kolektivních publikací zcela naplnit nepodařilo. Nic na tom nemění ani úvod (napsali oba editoři) a závěr knihy (I. Chorvát), které jsou stručné a vedle užitečné úvodní informace o genezi textu vlastně jen shrnují obsah kapitol. $Z$ tohoto důvodu v recenzi volím zdlouhavější cestu referování o každé jednotlivé kapitole zvlášté.

Právě I. Chorvát je autorem prvních dvou kapitol, které knize dávají, nebo se o to aspoň snaží, společný teoretický a historický rámec. Ve vstupní teoretické kapitole (kap. 1), kde se věnuje vymezení volného času a vývoji jeho pojetí v sociologii, ukazuje, jak z dnešního pohledu utopická očekávání Joffreho Dumazediera [Dumazedier 1962] a dalších autorů z šedesátých let minulého století, podle nichž vyspělé země měly brzy vstoupit do fáze společnosti volného času, vystřídal všeobecný pocit uspěchanosti a chronického nedostatku volného času. Vysvětlení pro tento jev Chorvát hledá v hlubokých ekonomických, kulturních a technologických proměnách a $\mathrm{v}$ procesu individualizace, které $\mathrm{v}$ posledních desetiletích zasáhly společnosti na celém světě. Samostatnou pozornost věnuje novému typu sociálního uspořádání podmíněnému rozmachem internetu a nových médií, který autoři jako (nezmiňovaný) Barry Wellman [2001] a (zmiňovaný, ale necitovaný) Manuel Castells [2001] označili termínem „zasítovaný individualismus" (networked individualism), a také měnícím se vzorcům trávení volného času u mládeže a kategorie tzv. mladých dospělých.

Teoretický rámec přiblížený v kap. 2 může dobře sloužit výzkumu volného času, ale kniha má ještě druhé hlavní téma, či spíše celý široký tematický okruh, životní styl, kulturní spotřebu a participaci. Definice životního stylu se objevuje až v předposlední kapitole (kap. 6), kulturní spotřeba a participace jsou aspoň 
částečně teoreticky ukotveny až v kapitole poslední (kap. 7). Nikde v knize není systematicky reflektováno, jaký je vztah mezi volným časem, životním stylem a kulturní spotřebou, potažmo mezi sociologií volného času, sociologií životního stylu a sociologií kultury.

Chorvát také napsal důležitou srovnávací kapitolu (kap. 2) o české a slovenské společnosti z hlediska jejich sociální struktury, hodnot, ekonomických podmínek, demografického vývoje, religiozity a chování populace v oblasti kultury, sportu a trávení dovolených. Zde je vyloženo schéma nestejné modernizace české a slovenské společnosti, které je v pozdějších kapitolách, ale s důležitou výjimkou poslední kapitoly, více méně univerzálně používáno k explanaci zjištěných rozdílů. V kostce řečeno, dřivější modernizace českých zemí poskytuje vysvětlení lepší infrastruktury pro kulturu a sport, dřívější hodnotové změny směrem k aktivnímu užívání volného času a individualizace životních stylů. Na Slovensku modernizace proběhla opožděně a unáhleně, i rychlá socialistická urbanizace země přinesla technický a sociální deficit, které dosud nejsou plně překonány. Také vývoj v oblasti volného času a životních stylů je tedy ve slovenské společnosti opožděný, proměny, kterými česká společnost už prošla, k východním sousedům přicházejí s fázovým posunem [Chorvát, Šafr 2019: 41-43, 57] ${ }^{1}$. Pozitivní stránkou tohoto přístupu je zjištění, častokrát se objevující v empirických analýzách, že Slovensko svůj modernizační handicap překonává a jeho zpoždění za českou společností se výrazně zmenšuje.

Modernizační teorie bývá kritizována pro unilineární a unifinální chápání cesty $\mathrm{k}$ modernitě ( $\mathrm{k}$ přehledu diskusí o modernizaci např. sborník Šubrt, Pfeiferová [2013]), tato kritika se však v př́ipadě dvou tak geograficky, historicky i kulturně si blízkých společností nezdá na místě. Těžko si představit, že by se Češi a Slováci mohli dopracovat ke dvěma velmi odlišným variantám modernity, tak jako to je naopak dobře představitelné třeba v př́ípadě Spojených států a Číny. Problém s modernizační teorií v případě této knihy spočívá v něčem úplně jiném. Modernizace je proces převážně charakterizovaný ekonomicky, technologicky, infrastrukturně. Má sice své koreláty v oblasti hodnotových změn, ale ty jsou patrně spíš produktem a prostředkem modernizace než jejím zdrojem. Tento pohled je spojený s rizikem, že svým ekonomickým determinismem pohltí symbolickou autonomii, jakkoli relativní a částečnou, životních stylů a kulturního jednání.

\section{Proměny hodnot a aktivit v oblasti volného času}

Následujících pět kapitol přináší výsledky empirického zkoumání různých rovin a aspektů volného času a životních stylů v české a slovenské společnosti. Všechny tyto kapitoly více nebo méně věrně dodržují jeden vzor uspořádání: teoretická východiska - historický kontext - výsledky empirických analýz a jejich diskuse

\footnotetext{
${ }^{1}$ Na recenzovanou publikaci je dále odkazováno způsobem [s. číslo stránky].
} 
- na závěr zodpovězení otázky, co mají česká a slovenská společnost v daném ohledu společného a v čem se naopak liší.

Věra Patočková (kap. 3) se věnuje rozdílům v zastávaných hodnotách souvisejících s prací a volným časem v obou zemích na základě dat z European Value Study (EVS) a European Working Conditions Survey (EWCS). Z mnoha uváděných empirických výsledků lze zmínit jen pár. Význam volného času po roce 1989 trvale stoupá, v ČR vzrostl nejvíce ve druhé dekádě po pádu komunistického režimu, v SR až ve třetí dekádě. Práce je důležitější hodnotou pro Slováky než pro Čechy. V ČR význam práce až do ekonomické krize let 2007-2008 klesal, v další dekádě však opět stoupl. Kapitola přináší důležitá data z výzkumů hodnot, ale je popisná a závislá na otázkách z šetření. Je otázka, jestli výklad o volném čase v české a slovenské společnosti musí začínat od Aristotela. Koncept „hlavního životního zájmu“ může být v určitých kontextech stále užitečný, ale je dobré si připomenout, že Robert Dubin jej formuloval už v polovině padesátých let 20. století [Dubin 1956].

Navazující kapitola I. Chorváta a J. Šafra (kap. 4) sleduje, jak se v obou zemích $\mathrm{v}$ posledních desetiletích volnočasové aktivity měnily a jaké socioekonomické a demografické síly na ně působily. Spojením vhodných dat z československého výzkumu třídní a sociální struktury z roku 1984 (TSS 1984), výzkumu Sociální stratifikace ve východní Evropě po roce 1989 (SSVE) z roku 1993 a z výzkumů ČR 2011 a SR 2016 autoři získali cennou možnost náhledu do volnočasových aktivit Čechů a Slováků od osmdesátých let až téměř do současnosti. Jeden ze zajímavých závěrů srovnání zní, že navzdory počítačům a internetu čeští i slovenští občané v současnosti tráví častěji svůj čas kulturními a sportovními aktivitami mimo domov a mají více společenských kontaktů s přáteli a známými než v roce 1984 [s. 101]. Další analýza se na základě dat z evropského výběrového šetření Životní podminky (EU-SILC) věnuje participaci na kulturních a sportovních událostech. Česká populace je aktivnější, ale u mladších ročníků a vysokoškoláků se rozdíly stírají. Největší rozdíl mezi ČR a SR existuje v navštěvování kulturních a historických památek. Vysvětlení autoři hledají, jak už bylo řečeno výše, v dřívější modernizaci a urbanizaci českých zemí, která se projevuje lepší infrastrukturou pro kulturní participaci a silnější orientací českého obyvatelstva na aktivní trávení volného času [s. 110-111].

Následující část kap. 4 zkoumá rozdíly v četnosti kontaktů s přáteli a příbuznými a v účasti na činnosti spolků podle dat z výzkumu ISSP Sociální sítě a sociální zdroje z roku 2017. V intenzivních kontaktech s rodinou a přáteli naopak Slováci vítězí nad Čechy. Stejně srovnání mezi oběma národy dopadá i pro oblast zapojení do spolkové činnosti a činnosti politických stran. Autoři z těchto zjištění vyvozují závěr, že v SR je dosud silněji př́itomná starší, lokálně komunitní forma trávení volného času, zatímco v ČR tento druh vazeb a aktivit ustoupil individualizovaným formám životního stylu [s. 116]. K tomu se dá na okraj poznamenat, že zjištění o vyšší spolkové aktivitě Slováků se sice na jednu stranu nachází v souladu s výsledky jiných výzkumů (například různých vln EVS a World Values 
Survey), ale na stranu druhou není bez dalšího upřesnění teoretického výkladu slučitelné s tezí o nižším stupni modernizace slovenské společnosti. Nejvyspělejší západní země totiž vykazují ještě mnohem vyšší hodnoty členství ve spolcích a sdruženích než Slovensko. Kde je bod, kdy spolková účast přestává být indikátorem zaostalého komunitního uspořádání a stává se projevem společenské modernity?

K náročnějším otázkám se kap. 4 dostává ve své závěrečné části, která se táže, zda způsoby trávení volného času v ČR a SR jsou nějak vnitřně strukturovány a jaké sociodemografické faktory determinují různé životní styly. Analýzou hlavních komponent na spojených datech z výzkumů ČR 2011 a SR 2016 autoři dospěli k pěti komplexům volnočasových aktivit: (1) vysoké kultuře, (2) mužskému světu zábavy mimo domov, (3) ženskému světu kontaktů v rodině a se známými, (4) pasivnímu trávení volného času mladými lidmi doma, spojenému s konzumací médií pro mládež, (5) pasivnímu trávení času doma, převážně u televize, lidmi spíše staršími. Aktivity typu 1, 4, 5 jsou častější v ČR, u typu 3 rozdíl není statisticky významný, pouze typ 2 je častější ve slovenské populaci [s. 123]. Ze sledovaných sociodemografických charakteristik má na podobu trávení volného času největší vliv místo bydliště, což souvisí s velkým rozvojovým rozdílem mezi městy a venkovem zejména na Slovensku.

\section{Nové stránky volného času: internet a nákupní centra}

V kap. 5 se Milan Zeman zabývá dvěma různými a navzájem jen volně souvisejícími tématy: vlivem nových informačních a komunikačních technologií (IKT) na trávení volného času a nakupováním v nákupních centrech. Di̊vod tohoto spojení asi není jiný než ten, že obě témata bylo třeba mít v knize o volném čase zahrnuta. Obě části mají spíše informativní a přehledovou povahu, ale vedle základních fakt o vývoji $\mathrm{v}$ daných oblastech a velmi stručného představení problematiky digitální propasti přinášejí i výsledky několika empirických šetření. Zjištění z výzkumů ISSP Volný čas a sport 2007-2008, Eurobarometer a samozřejmě také SR 2011 a SR 2016 ukazují o něco lepší přístup k internetu a informačním technologiím v české společnosti, ale data o chování obyvatel obou zemí na internetu jsou dost podobná. Pětiletý rozdíl mezi českým a slovenským výzkumem však v případě tak rychle se vyvíjející oblasti opravdu znamená, jak upozorňuje M. Zeman, ohrožení validity př́slušných srovnání [s. 140].

I když se dá rozumět tomu, že nemusela být $\mathrm{k}$ dispozici vhodná data, je škoda, že rozbor vztahu mezi IKT a volným časem nešel do větší šířky a hloubky. V první kapitole knihy I. Chorvát v návaznosti na předchozí studie [Lupač 2015] zdůraznil, že v zasítovaném individualismu nerostou jen široké sítě slabých a instrumentálních kontaktů, ale také velmi pevné vazby $\mathrm{k}$ menším skupinám jedinců spojených prátelskými nebo rodinnými pouty [s. 33]. Má-li být prokázána užitečnost prredstavy o zasítovaném individualismu pro pochopení toho, 
co se v současnosti děje $\mathrm{v}$ české a slovenské společnosti, bylo by třeba empiricky prozkoumat, zda a jakým směrem se pod vlivem internetové sociability proměňují vzorce trávení volného času a životní styly nejen online, ale také, a možná především, offline.

Také v př́ípadě nákupních center jsou data o jejich navštěvování v ČR a SR značně podobná, i když v ČR je o něco více častějších návštěvníků. Zatímco mezi Čechy nakupování v nákupních centrech láká všechny generace zhruba stejně, na Slovensku je zájem o nákupní centra nepřímo úměrný věku.

\section{Sport a modernizace}

Stále významnější oblastí trávení volného času je sport, kterému se věnuje Roman Hofreiter v kap. 6. Svou analýzu začíná historickosociologickou studií vývoje česko-slovenského sportu, z níž ve shodě s modernizačním výkladovým rámcem knihy vyvozuje závěr o infrastrukturním deficitu sportu v SR. Že nejde jen o rozdíly z velmi vzdálené minulosti, ukazují data z výzkumu TSS 1984. Podle nich byl ještě v první polovině osmdesátých let rozdíl ve vybavenosti sportovními potřebami mezi českými a slovenskými občany $46 \%$ ku $27 \%$ a výrazně více Čechů také zvládalo základní sporty [s. 157-158]. Novější vývoj Hofreiter dokumentuje na datech z šetření ISSP, Eurobarometer a dvojice výzkumů ČR 2011 a SR 2016. Podobně jako jiné nové trendy také „zdravý životní styl“ pronikl do ČR o něco dřive než na Slovensko, ale v současné době již jsou rozdíly mezi oběma zeměmi poměrně malé. Mezi lety 1995 a 2004 se podíl často sportujících Čechů zvýšil na dvojnásobek, na Slovensku proběhl o něco menší skokový nárůst až mezi lety 2004 a 2016. Intenzita sportování v obou společnostech roste s vyšším umístěním v třídní struktuře (podle zjednodušeného EGP schématu) a v nejvyšších třídách jsou rozdíly mezi Českem a Slovenskem obzvláště malé. Autor také pomocí logistického regresního modelu odhadl, jaké charakteristiky mají častí sportovci: samožrejmě jsou mladí, vedle toho pracují nemanuálně, jsou vzdělaní a pocházejí $z$ rodin vzdělaných rodičů, $v$ neposlední řadě nežijí na venkově [s. 165]. Ke sportu patří členství ve sportovních klubech nebo svazech a navštěvování zápasů. Zatímco Češi jsou výrazně častěji členy sportovních sdružení (i tento fakt přispívá k pochybnostem o správném výkladu už uvedeného zjištění o vyšší účasti Slovákư ve spolcích), Slováci zejména díky fenoménu vesnického fotbalu vedou jako diváci při sportovních utkáních [s. 170-172].

\section{Kulturní spotřeba}

Poslední kapitola (kap. 7), kterou napsali Miroslav Paulíček a J. Šafr, do záběru knihy přidává dosud téměř nedotknuté téma vlivu médií na trávení volného času a podrobněji prozkoumává oblast kulturní participace a spotřeby, především však rozšiřuje teoretická východiska analýzy o bourdieuovské koncepty vkusu 
a homologie mezi prostorem životních stylů a sociálním prostorem. Už fakt, že před touto kapitolou byl Pierre Bourdieu zmíněn jen jednou a mimochodem, vyvolává pochybnost o jednotném teoretickém rámci celé knihy. Spíše se zdá, že každý editor pracoval se svým vlastním rámcem, a protože je těžké, ba nemožné je sloučit do koherentního širšího rámce, Šafrovo neobourdieuovské pojetí životního stylu se objevuje jen v kontextu jeho vlastních analýz. K otázce teoretické koherence knihy jako celku ještě bude př́iležitost se vrátit, nyní zpět k závěrečné kapitole, která přináší některá zajímavá zjištění, ale snaží se toho udělat příliš mnoho a je poněkud nesourodá.

Její první, "teoretická" třetina obsahuje obecnější zamyšlení nad vlivem médií a informačních technologií na kulturní chování a spotřebu. Tato část by možná lépe zapadla do Chorvátovy první teoretické kapitoly, na svém současném místě totiž stejně neplní roli teoretického rámce pro následující empirické analýzy. Svou bezprostřední inspiraci čerpá zejména $z$ analýzy účinkủ médií na společnost, kterou už v osmdesátých letech vypracoval americký mediální teoretik Joshua Meyrowitz (česky vyšla až o 20 let později [Meyrowitz 2006]): splývání světů dospělých a dětí, rozmazávání rozdílu mezi veřejnou a soukromou sférou, odpoutávání médií od lokality. Simmelovská analýza sluchátek jako fenoménu ztělesňujícího delokalizaci je výstižná, ale jak si vzpomene leckterý prošedivělý čtyřicátník, i sluchátka a walkmany tu už byly v osmdesátých letech.

Druhá část kap. 7 se zabývá rozdíly v kulturním chování Čechů a Slováků. Tyto rozdíly nejsou velké, Češi o něco více čtou a sledují doma filmy. Ve shodě s modernizační teorií na Slovensku méně čte zejména starší generace a obyvatelé venkova. Modernizační teze platí i v případě domácího sledování filmů, přičemž se v obou zemích projevuje opačnými vztahy. V Česku filmy sledují spíše méně vzdělaní lidé žijící na venkově, na Slovensku vzdělanější lidé z měst [s. 185, 188]. V účasti na kulturních aktivitách mimo domov vedou Češi, výjimkou je folklorní tanec, který je mnohem populárnější na Slovensku [s. 191]. U oblíbenosti televizních pořadů autoři postoupili od zaznamenávání česko-slovenských rozdílů až k otázce, zda se u českých a slovenských diváků projevuje něco jako konzistentní vkus. Faktorovou analýzou na spojených datech za obě společnosti odhalili tři typy vkusu: vkus pro ženské masové pořady, mužský mainstreamový vkus a vysokokulturní vkus.

\section{Otázky kolem homologie životních stylů a sociální struktury}

Cílem závěrečné třetiny kap. 7, která je nesporně jejím obsahovým těžištěm, je empiricky zjistit nejen to, zda v české a slovenské společnosti existují různé vyhraněné podoby vkusu, ale také zda se odlišné druhy vkusu, a tedy odlišné životní styly ustavují v závislosti na sociálním postavení svých nositelů. Empirickému testu jsou podrobeny tři konkurující si teoretické modely známé z rozsáhlé zahraniční literatury k výzkumnému tématu vkus a sociální třídy: (1) bourdieuovská 
homologie mezi pozicemi v sociálním prostoru a životními styly, (2) postmoderní teze o individualizaci vkusu a spotřebního chování, (3) teorie Richarda Petersona o kulturním všežroutství, která je v kapitole chápána jako jakýsi střední bod mezi předchozími dvěma teoriemi. J. Šafr podobné analýzy, se stejným teoretickým rámcem a některé i na stejných datech z výzkumu ČR 2011, zpracoval už dř́ve a zde na ně navazuje [zejména Šafr 2012, 2014], novum v nynější studii představuje, nebo by aspoň mělo představovat srovnání české a slovenské společnosti.

Ověření teze o všežroutství je bohužel věnován jen malý prostor a je založeno na dvou nepř́liš přesvědčivých indikátorech. Jedním je občasné chození na koncerty různých žánrů hudby (s frekvencí aspoň jednou za rok), druhým pak domácí konzumace filmů $\mathrm{v}$ souběhu s konzumací knih [s. 196]. V posledním případě nelze vyloučit, že mnozí jednotlivci sledují filmy a čtou knihy, které si jsou úrovní své kulturní legitimity navzájem podobné, nejedná se tedy nutně o všežrouty. Proti prvnímu indikátoru je možné namítnout, že k účasti na koncertech žánrově odlišné hudby jednou ročně může dojít i na základě nahodilých faktorů nebo z důvodů společenského tlaku okolí, a taková účast tedy vypovídá jen málo o jedincových preferencích, zejména však může být způsobena omezenou nabídkou koncertů oblíbeného žánru v blízkosti místa bydliště - tomu by odpovídalo neočekávané zjištění, že na Slovensku je takových „všežravých" návštěvníků koncertů mnohem více než v Česku (11 \% proti 4 \%). Spolehlivějším výsledkem této partie analýzy je zjištění, že v obou zemích jsou omnivorové spíše mladí a vzdělaní.

Homologie životního stylu a umístění v sociální struktuře je doložena na grafech z vícenásobné korespondenční analýzy (MCA) vytvořených zvlášt pro českou a slovenskou společnost. Tyto grafy ne náhodou připomínají Bourdieuovu Distinkci, ale znamenají něco trochu jiného. Místo množství a složení ekonomického a kulturního kapitálu (Bourdieu) se v česko-slovenské analýze staly definující charakteristikou horizontální osy diferenciace životních stylù životní fáze (věk) a pohlaví, vertikální osy pak socioekonomický status indikovaný vzděláním. To může být platný empirický výsledek, ale homologii mezi životními styly a takto vymezeným sociálním prostorem by bylo třeba i nějak teoreticky vysvětlit. V Bourdieuho pojetí homologie hraje klíčovou roli třídní habitus [Bourdieu 1989: 19]. Zjištění o silné diferencující roli životní fáze úlohu třídního habitu, který by měl být vůči působení času relativně odolný, přinejmenším zpochybňuje.

Fakt, že z MCA nevyšly jako dvě hlavní dimenze objem a složení ekonomického a kulturního kapitálu, sám o sobě nezakládá důvod k tvrzení o „slábnoucí homologii“" mezi sociálními pozicemi a životními styly [s. 201]. K tomu jednoduše chybí srovnání s daty $\mathrm{z}$ dřívějšího nebo pozdějšího období a také informace o tom, jak velkou část variance $\mathrm{v}$ datech vysvětluje ekonomický a kulturní kapitál v Bourdieuho smyslu. Z početných studií dokládajících růst sociálních nerovností v posledních letech by se dalo spíše vyvodit očekávání, že třídní homologie naopak postupně sílí. Autoři však homologii považují za nedostatečně prokázanou a místo ní se zejména ve vztahu k mladší generaci Čechů a Slováků přiklánějí - bohužel bez empirického důkazu - k už zmiňované tezi o zasítovaném 
individualismu [s. 32, 202]. Pravděpodobně by však vysvětlení významu životní fáze a pohlaví pro diferenciaci životních stylů bylo třeba hledat především v dramatické resocializaci obou společností po roce 1989 a v dlouhodobě působících ekonomických a kulturních faktorech ovlivňujících dělbu práce mezi pohlavími.

Otázka, zda se vztahy (homologie) mezi prostorem sociálních pozic a prostorem životních stylů $\mathrm{v}$ české a slovenské společnosti navzájem podobají, nebo se v něčem podstatném liší, není explicitně zodpovězena. Srovnání grafů MCA [s. 200-201, graf 7.9] pro českou a slovenskou společnost nicméně ukazuje určité rozdíly. Diferencující vliv věku se zdá být na Slovensku mnohem menší než v Česku a menší je i vliv vzdělání. Která sociální charakteristika je na Slovensku rozhodující pro diferenciaci podél dominantní svislé osy, není vůbec zřejmé. Proměnná př́ijem v grafech chybí.

\section{Nejednotná koncepce, bílá místa, impulzy pro další výzkum}

Závěrem ještě zbývá pootočit pohled od jednotlivých kapitol k celku. Jako by se v knize křížily dvě různé koncepce, jež není snadné sjednotit, a úplně se to nepovedlo. Výzkum volného času („,Chorvátova část“) nebyl plně integrován s výzkumem vkusu a kulturního chování („,Šafrova část“) a někde mezi nimi uprostřed se vznáší problematika životního stylu. Oba hlavní segmenty mají svou vlastní teorii a explanační schémata, $\mathrm{v}$ důsledku kapitola o vkusu a kulturní spotřebě se zbytkem knihy úplně neladí.

Jiným napětím, které v knize bylo nutné překonat, a částečně se to povedlo, částečně ne, je napětí mezi vysvětlujícím přístupem a přístupem spíše jen popisným. Česko-slovenská komparace je nepochybně silnou stránkou knihy, ale neustálá potřeba porovnávat a na datech dokládat vývoj v jedné a druhé společnosti zvýraznila popisné prvky na úkor vysvětlování a hlubší interpretace dat vycházející z pojmů a teorií. Většina zjištění byla vysvětlena teorií různých fází modernizace, ale je to všechno, co se dá říci o prř́činách rozdílů $\mathrm{v}$ životních stylech mezi dvěma společnostmi?

Odtud je již jen malý krok k oblíbenému žánru recenzentů, „,co v knize není a mělo by být ${ }^{\prime \prime}$. Spíše bych však mluvil o tom, jaká další neprobádaná místa studie pomohla odhalit. V oblasti volného času se jeví jako nezbytné vzít v potaz fenomén deviantních aktivit offline i online (dark leisure), jejichž existence není v knize téměř ani naznačena [Rojek 1999]. Dále by např́klad mohlo být pro lepší vhled do toho, kým Slováci a Češi ve volném čase jsou a co dělají, užitečné v návaznosti na Roberta Stebbinse zkoumat modality vážného a př́ležitostného volného času a kariéry osob, které ve volném čase uskutečňují své identitní projekty [Stebbins 2007]. Pozornost by si zasloužil také vývoj fenoménu neformálního a formálního dobrovolnictví, který se nachází na rozhraní volného času, občanské společnosti a sféry placené práce, ale do výzkumu volného času a životního stylu nepochybně patří [Lockstone-Binney et al. 2010]. 
Jsou životní styl a kulturní chování jen odrazem ekonomiky, technologií a demografické struktury? Existuje něco jako česká kultura a slovenská kultura a má toto něco svou vlastní vývojovou setrvačnost, kterou socioekonomické síly nemohou jednoduše anulovat? Tuto možnost autoři téměř nereflektují, ale stojí za povšimnutí, že na několika místech výklad kolísá mezi stanoviskem, že životní styl je produkt socioekonomických podmínek, a velmi odlišným názorem, že životní styl je samostatný explanans konkrétního chování [s. 110]. Jak už bylo naznačeno ve vztahu ke kap. 2 , analýzy provedené v této knize se nevyznačují velkým porozuměním pro symbolickou a významovou rovinu životních stylů. V tomto i v některých jiných výše uvedených kritických ohledech je práce I. Chorváta, J. Šafra a kol. možná více, než by sami chtěli, blízká předlistopadové československé tradici výzkumu životního způsobu, v níž jasně převládaly (když vynecháme její ideologickou komponentu) jednostranný socioekonomický determinismus a metodologický empiricismus.

Pojem "subkultura“ se v textu objevuje málokdy, „scéna“ nebo „kmen“ vůbec, třebaže významná část nabídky současných životních stylů a repertoárů kulturního chování je bez zohlednění dynamiky subkultur a postsubkultur nepochopitelná [Bennett 2013]. Je jistě pravda, že data z mezinárodních šetření nám o vývoji subkultur a dalších specifických kulturních procesech říkají velmi málo. To je také jeden z důležitých důvodů, byț ne zdaleka jediný, proč je třeba nezůstávat $\mathrm{u}$ dotazníkových šetření, ale $\mathrm{v}$ ideálním př́ípadě makrosociologické analýzy založené na kvantitativních datech doplnit kvalitativními rozhovory, etnografií, analýzami kulturních významů.

Jistě není třeba uvádět další náměty pro př́íší směřování českých a slovenských výzkumů volného času, životního stylu a kulturní spotřeby. Autoři knihy Volný čas, společnost, kultura. Česko - Slovensko $\mathrm{k}$ jejich rozvoji dodali významný impulz.

Marek Skovajsa

Filozofická fakulta, Univerzita Karlova https://doi.org/10.13060/csr.2021.034

\section{Literatura}

Bennett, A. 2013. „Youth Culture, Leisure and Lifestyle: From Subcultures to Post-Subcultures." Pp. 593-605 in T. Blackshaw (ed.). Routledge Handbook of Leisure Studies. London: Routledge, https://doi.org/10.4324/9780203140505.ch48.

Bourdieu, P. 1989. „Social Space and Symbolic Power.“ Sociological Theory 7 (1): 14-25, https://doi.org/10.2307/202060.

Castells, M. 2001. The Internet Galaxy: Reflections on the Internet, Business, and Society. Oxford: Oxford University Press, https://doi.org/10.1093/acprof:oso/9780199255771.001.0001.

Dubin, R. 1956. „Industrial Workers' Worlds: A Study of the 'Central Life Interests' of Industrial Workers." Social Problems 3 (3): 131-142, https://doi.org/10.2307/799133.

Dumazedier, J. 1962. Vers une civilisation du loisir? Paris: Seuil. 
Chorvát, I., J. Šafr (eds.). 2019. Volný čas, společnost, kultura. Česko - Slovensko. Praha: Sociologické nakladatelství (SLON).

Lockstone-Binney, L., K. Holmes, K. Smith, T. Baum. 2010. „Volunteers and Volunteering in Leisure: Social Science Perspectives. “ Leisure Studies 29 (4): 435-455, https://doi.org/10.1080/02614367.2010.527357.

Lupač, P. 2015. Za hranice digitální propasti. Nerovnost v informační společnosti. Praha: Sociologické nakladatelství (SLON).

Meyrowitz, J. 2006. Všude a nikde: vliv elektronických médií na sociální chování. Praha: Karolinum.

Rojek, Ch. 1999. „Deviant Leisure: The Dark Side of Free-Time Activity.“ Pp. 81-96 in E. L. Jackson, T. L. Burton (eds.). Leisure Studies: Prospects for the Twenty-First Century. State College, Pa: Venture.

Stebbins, R. A. 2007. Serious Leisure: A Perspective for Our Time. New Brunswick, NJ: Transaction Publishers, https://doi.org/10.4324/9781315129167.

Šafr, J. 2012. „Životní styl po roce 1989.“ Pp. 231-265 in V. Patočková, D. Čermák, L. Vojtíšková a kol. Kultura v krajích České republiky. Praha: SOÚ AV ČR.

Šafr, J. 2014. „,Kulturní spotřeba a sociální distinkce v České republice." Pp. 114-143 in P. Zahrádka (ed.). Spotřební kultura. Historie, teorie a výzkum. Praha: Academia.

Šubrt, J., Š. Pfeiferová (eds.). 2013. Sociální změna. Praha: Fakulta humanitních studií UK.

Wellman, B. 2001. „Physical Place and Cyberplace: The Rise of Personalized

Networking." International Journal of Urban and Regional Research 25 (2): 227-252, https://doi.org/10.1111/1468-2427.00309. 